\title{
HYPOMAGNESAEMIA IN PREGNANCY: A PREDICTOR OF PRETERM LABOUR
}

\author{
SHAHID AR ${ }^{1}$, HOSNA AU ${ }^{2}$, TAHMINA HZ ${ }^{3}$
}

\begin{abstract}
:
Preterm birth is a major health concern. It is the leading cause of perinatal mortality and morbidity. Besides varied etiology, it may be due to alteration in basic biochemical function of the body at cellular level stating emphasis to trace elements of which magnesium, being one of them. Pregnancy is marked by a state of hypomagnesaemia and varied hypomagnesaemia is observed in preterm labour cases. The study is conducted to find out the relationship between low serum magnesium concentrations with preterm labour, with a view to ascertain it as one of the predictor of preterm labour. This study has been designed as cross sectional case control study. 100 pregnant women with preterm labour were taken as case and 100 women with term labour as control. It is found that mean level of serum magnesium was lower in preterm labour as compared with term labour. The study shows that there is significant decrease in magnesium in maternal body in case of preterm labour. The study also shows that the relative risk of preterm labour was 3.18 times more in patients with serum magnesium level less than $1.9 \mathrm{mg} /$ dl in comparison to those who had the level of $1.9 \mathrm{mg} / \mathrm{dl}$ or more. Low level of serum magnesium significantly correlated with the preterm labour. Moreover different studies also shows that the decreased serum magnesium level has an association with the uterine irritability leads to the preterm labour. As such, it is assumed that the low serum magnesium concentration in pregnancy has a role in pathophysiology of preterm labour and may be used as a predictor of preterm labour.
\end{abstract}

Key words: Hypomagnesaemia, predictor, preterm labour.

(J Dhaka Med Coll. 2010; 19(1) : 51-57)

\section{Introduction:}

Preterm labour is defined as labour occurs with regular, and frequent uterine contractions causing progressive cervical changes before 37 completed weeks of gestation ${ }^{1}$. It accounts for $10-15 \%$ of all pregnancies. The incidence varies with population studied. It is a major cause of perinatal mortality and morbidity ${ }^{2}$.

The cause of preterm labour is not yet completely known; in $50 \%$ cases it is spontaneous and idiopathic, although several potential risk factors have been identified. The main one among them is premature rupture of membrane (PROM), and others are multiple pregnancy, polyhydramnios, hypertensive disorder of pregnancy, infection, cervical incompetence, antepartum haemorrhage, fetal and uterine anomalies, anaemia, heavy work, smoking etc. It is also related to socioeconomic status and geographic location ${ }^{3,4,5}$.
Basic biochemical functions of our body are maintained by various minerals, water, trace elements etc. Magnesium is one of the trace elements, a bivalent cation and necessary for life. Besides varied etiology of preterm labour, it may be due to alteration in basic biochemical function of body at cellular level stating to trace elements of which magnesium, being one of them, is subject of interest now a days. It is found that pregnancy is marked by a state of hypomagnesaemia and varied hypomagnesaemia is observed in preterm labour cases. So it is believed that magnesium plays a vital role in preterm labour ${ }^{6,7}$. The variation of serum magnesium level during normal pregnancy as well as in pregnancy with various disease states has been the subject of continued interest. Magnesium is a cofactor in more than 300 enzyme reactions. It

1 Lecturer, Department of Anatomy, Dhaka Medical College, Dhaka.

2 Assistant Professor, Department of Obstetrics and Gynaecology, Bangabandhu Sheikh Mujib Medical University, Dhaka.

3 Consultant, Chuadanga Sadar Hospital, Chuadanga.

Correspondence: Dr. Asma Rumanaz Shahid 
activates those enzymes and plays an important role in the mechanism of nerve conduction, uterine contractility and contractile response of other smooth muscles. Magnesium antagonizes the action of calcium. It also has an action on uterine myometrium causing it to relax by stimulating $\alpha 2$ adrenergic receptor and cyclic AMP. It competes with calcium ion which brings about inhibition of myosine kinase and therefore, a drop in phosphorylated myosine ${ }^{8}$. Another possible way by which hypomagnesaemia induces uterine irritability by inhibition of adenyl cyclase with resultant increase in cytoplasmic calcium leve1 ${ }^{9}$. Thus hypomagnesaemia during pregnancy decrease the magnesium level in myometrium and a low magnesium concentration in pregnant human myometrium could be a cause of preterm labour ${ }^{10,11,12}$. Rising serum magnesium level serves to relax the uterine smooth muscle, thereby providing the basis for the use of magnesium sulphate as a tocolytic agent. So this low serum magnesium concentration in pregnancy could be a cause of preterm labour. As the etiology of preterm labour is multifactorial, the attempts to predict it are not very successful and accurate. Clinically, it would be useful to be able to predict who will deliver preterm. The predictors may be used in the management of women at high risk for preterm labour, such as women with previous preterm labour and also can be used as a part of a management protocol to individualize patient care ${ }^{13}$. Therefore, we may conclude that there is an association between hypomagnesaemia in pregnancy with premature onset of labour and estimation of serum magnesium in pregnancy may proved to be a valuable tool in predicting preterm onset of labour ${ }^{6,14}$.

\section{Materials and Methods:}

This is a cross sectional case control study. This study has been carried out in the Department of Obstetrics and Gynaecology, Dhaka Medical College Hospital for a period of 1 year starting from May, 2005 to April, 2006.
A total number of 200 women were selected by consecutive sampling method for the study having age range between 16 to 40 years with considering some inclusion and excusion criteria and they were grouped as follows:

GROUP-I (Case) - 100 cases with preterm labour occurring after 28 weeks and before 37 completed weeks of gestation.

GROUP-II (Control) - 100 women with term labour that is after 37 completed weeks of gestation.

Venous blood was drawn from entire subject to evaluate the serum magnesium level at morning and sent immediately to laboratory for analysis. The serum magnesium analysis was done in the laboratory by using Xylidyl Blue Colorimetric Method. The reference value for normal serum magnesium is $1.9-2.5 \mathrm{mg} / \mathrm{dl}^{15}$.

Statistical analysis has been carried out using SPSS version 11.0. Parametric data is expressed in mean $\pm \mathrm{SD}$ and evaluated by unpaired student ' $t$ ' -test, correlation coefficient test and Chi-square test for determining the difference as needed. Significance is defined as $\mathrm{p}$ value $<0.05$.

\section{Results:}

A total of 200 subjects were studied in Dhaka Medical College Hospital. Among them 100 patients were preterm labour and 100 were term labour cases. All the pregnant women were admitted in Dhaka Medical College Hospital and under observation till delivery. Relevant medical, menstrual, and obstetrical history were taken from all the subjects along with clinical examination. Venous blood was drawn from the entire subject to evaluate the serum magnesium level.

The observation and findings (mean $\pm \mathrm{SD}$ ) about the age, parity, nutritional status, occupation, previous obstetric history, history of abortion and previous preterm labour and fetal weight and outcome have shown in different tables.

Table-I revealed that the percentage of history of abortion is higher in group I patients (41\%) than group II $(30 \%)$, which is not statistically significant. 
Table-II revealed that among group I patient highest percentage had preterm labour (46.0\%) compared to group II $(28.0 \%)$ and the difference was statistically significant.The relative risk indicated that the risk of preterm labour is 2.190 higher among the patients with history of previous preterm labour.

Table-III indicates that $60 \%$ of group I patients had serum magnesium level less than $1.9 \mathrm{mg} /$ $\mathrm{dl}$; whereas it was only $32 \%$ in group II patients.

The odd ratio (OR) indicates that the risk of preterm labour is 3.19 times higher among the patients with low serum magnesiu less than $1.9 \mathrm{mg} / \mathrm{dl}$.

Table-IV shows that the mean serum magnesium level of the patients was lower than the patients who had no history of preterm labour, but the mean differnce is not statistically significant $(p>0.5)$.

The correlation between serum magnesium level and gestational age $\mathrm{a}(\mathrm{r}=0.25)$ is shown in Fig. -1 , which is a weakly positive correlation $(\mathrm{p}<0.05)$

Table-I

Distribution of the study patients by history of abortion

\begin{tabular}{|c|c|c|c|c|c|}
\hline \multirow[t]{3}{*}{ Variables } & \multicolumn{4}{|c|}{ Study patients } & \multirow[t]{3}{*}{$\mathrm{p}$ value } \\
\hline & \multicolumn{2}{|c|}{ Group I (n=100) } & \multicolumn{2}{|c|}{ Group II $(\mathrm{n}=100)$} & \\
\hline & No. & $\%$ & No. & $\%$ & \\
\hline \multicolumn{6}{|c|}{ History of abortion } \\
\hline Yes & 41 & 41.0 & 30 & 30.0 & 0.104 \\
\hline No & 59 & 59.0 & 70 & 70.0 & \\
\hline
\end{tabular}

Group I: patients with preterm labour

Group II: Patients with term labour

$\mathrm{p}$ value reached from Chi-square test

Table-II

Distribution of the study patients by history of previous preterm labour

\begin{tabular}{|c|c|c|c|c|c|}
\hline \multirow{3}{*}{$\begin{array}{l}\text { History of previous } \\
\text { preterm labour }\end{array}$} & \multicolumn{4}{|c|}{ Study patients } & \multirow[t]{3}{*}{$\mathrm{p}$ value } \\
\hline & \multicolumn{2}{|c|}{ Group I $(n=100)$} & \multicolumn{2}{|c|}{ Group II $(\mathrm{n}=100)$} & \\
\hline & No. & $\%$ & No. & $\%$ & \\
\hline Yes & 46 & 46.0 & 28 & 28.0 & 0.008 \\
\hline No & 54 & 54.0 & 72 & 72.0 & \\
\hline
\end{tabular}

Group I: patients with preterm labour

Group II : Patients with term labour

$\mathrm{p}$ value reached from Chi-square test

$\mathrm{RR}=2.190(95 \% \mathrm{CI}=1.217-3.942)$

Table-III

Distribution of the study patients by serum magnesium level

\begin{tabular}{|c|c|c|c|c|c|}
\hline \multirow{3}{*}{$\begin{array}{l}\text { Serum magnesium } \\
(\mathrm{mg} / \mathrm{dl})\end{array}$} & \multicolumn{4}{|c|}{ Study patients } & \multirow[t]{3}{*}{$\mathrm{p}$ value } \\
\hline & \multicolumn{2}{|c|}{ Group I (n=100) } & \multicolumn{2}{|c|}{ Group II $(\mathrm{n}=100)$} & \\
\hline & No. & $\%$ & No. & $\%$ & \\
\hline$<1.9$ & 60 & 60.0 & 32 & 32.0 & \\
\hline e"1.9 & 40 & 40.0 & 68 & 68.0 & \\
\hline Mean \pm SD (mg/dl) & & & & & 0.001 \\
\hline
\end{tabular}

Group I: patients with preterm labour

Group II : Patients with term labour

$\mathrm{p}$ value reached from unpaired Student's ' $\mathrm{t}$ ' test

Relative risk $=3.188(95 \%$ CI $1.784-5.694)$ 
Table-IV

Relationship between serum magnesium and history of previous preterm labor

\begin{tabular}{lccccc}
\hline History of preterm labour & $\mathrm{N}$ & \multicolumn{2}{c}{ Serum total magnesium $(\mathrm{mg} / \mathrm{dl})$} & $\mathrm{p}$ value \\
\cline { 3 - 5 } & & Mean $\pm S D$ & Min & Max & \\
\hline No & 126 & $2.02 \pm 0.4$ & 1.40 & 3.00 & 0.058 \\
Yes & 74 & $1.92 \pm 0.4$ & 1.30 & 3.00 & \\
\hline Total & 200 & $1.98 \pm 0.4$ & 1.30 & 3.00 & \\
\hline
\end{tabular}

$\mathrm{p}$ value reached from unpaired Student's ' $\mathrm{t}$ ' test

Table-V

Comparison of the previous studies on serum magnesium level in preterm labour with the current study 6,7,14,25,26

\begin{tabular}{lcc}
\hline \multicolumn{1}{c}{ Reference } & $\begin{array}{c}\text { Serum magnesium } \\
\text { level }-\mathrm{mg} / \mathrm{dl} \text { (mean } \pm \mathrm{SD})\end{array}$ & P- value \\
\hline $\begin{array}{l}\text { Kurzel RB, 1991: Serum Magnesium Level in Pregnancy } \\
\text { and in Preterm Labour. American Journal of perinatol; }\end{array}$ & $1.60 \pm 0.46$ & $<0.0005$ \\
08: 119-127. & $1.67 \pm 0.23$ & $<0.001$ \\
$\begin{array}{l}\text { Pushpo D and Jagdish WMA, 1991: A Study of Serum } \\
\text { Magnesium Level in Preterm Labour. The Journal of }\end{array}$ & \\
$\begin{array}{l}\text { Obstetrics and Gynaecology of India; 41:269-273. } \\
\text { Smolarczyk KR et al., 1997: Serum Magnesium Level in }\end{array}$ & $1.64 \pm 0.07$ & $<0.003$ \\
$\begin{array}{l}\text { Preterm Labour. International Journal of Obstetrics } \\
\text { and Gynaecology; 57: 443-483. }\end{array}$ & \\
$\begin{array}{l}\text { Wojcieka J et al., 1998: Serum Magnesium in Preterm Labour. } \\
\text { International Journal of Obstetrics and }\end{array}$ & $1.63 \pm 0.053$ & $<0.001$ \\
$\begin{array}{l}\text { Gynaecology; 61: 125 125. } \\
\text { Begum H et al.s, 2004; Relationship of Preterm Labour with } \\
\text { Serum Magnesium Level. Bangladesh J Obstetrics } \\
\text { and Gynaecology, 19(1): 3-6. }\end{array}$ & $1.77 \pm 0.36$ & $<0.001$ \\
Present Study & & \\
\hline
\end{tabular}

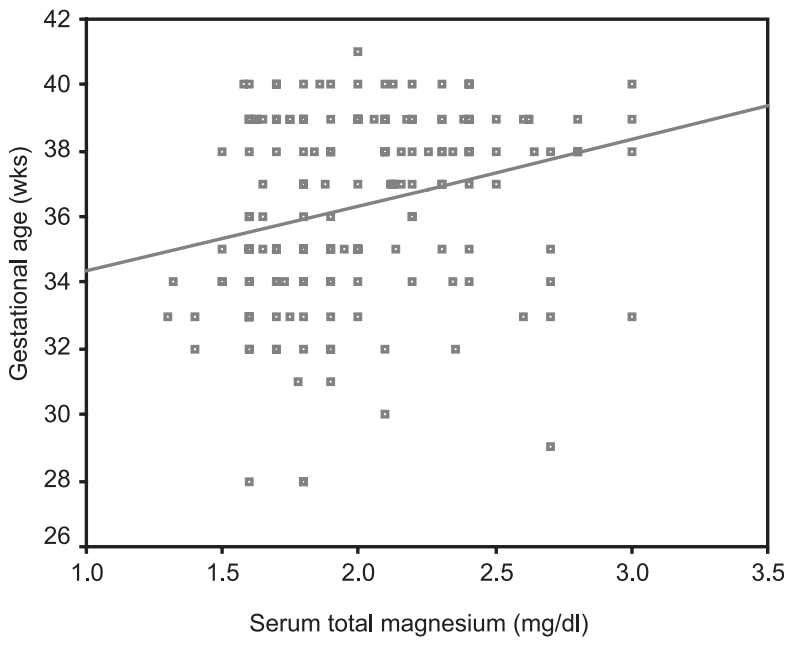

Fig.-1: Correlation between serum magnesium level and gestational age $(n=200)^{5.8}$

\section{Discussion:}

The cause of preterm labour is not yet completely known, although some risk factors have been identified recently, but none completely explain all preterm labour. However recently, involvement of magnesium in many physiological and pathological processes has been clearly verified. There are several studies and reports concerning the evidence of low magnesium in serum causes for preterm labour.

In this study two main approaches have been done to understand the etiology and pathophysiology of preterm labour. The first one is determination of serum magnesium level both in preterm and term pregnancy and compare the 
results of cases with that of the controls. The other approach is to find out the association of low serum magnesium level with the idiopathic group of preterm labour, with detail statistical analysis between different parameters of preterm labour and serum magnesium level.

The main focus of this study is serum magnesium level in preterm labour and its relation with the etiology of preterm labour.When compared with the term labour, the serum magnesium concentration is found as markedly reduced in preterm labour.

Past studies and reports have appeared showing a decreased level of serum magnesium in preterm labour. The present study has dealt with the concentration of serum magnesium in significant number of patients with preterm labour that is suppose to play an important role on the etiology of preterm labour if the serum magnesium level is low.

In present study, serum magnesium level has estimated in 100 patients with preterm labour and similar numbers of patients with term labour. It is found that serum magnesium level to be significantly reduced in the cases of preterm labour. Therefore the finding in the current study demonstrated that serum magnesium concentration is decreased in preterm labour. In this study it is found that the patients belonging to lower gestational age have lower serum magnesium level than the patient with higher gestational age. In this study the mean magnesium was $1.87 \pm 0.34$ $\mathrm{mg} / \mathrm{dl}$ for the patients with preterm labour and $2.10 \pm .04 \mathrm{mg} / \mathrm{dl}$ for those with term labour. The mean difference was found to be statistically significant $(\mathrm{p}<0.001)$. This result is also found similar to and supported by the study findings of other investigators. In a study carried out by Puspo and Jagdish (1990) serum magnesium level in preterm labour was found to be $1.67 \pm 0.23 \mathrm{mg} / \mathrm{dl}^{7}$. Kurzel found that the patients with preterm labour had significantly depressed serum magnesium level and the mean was $1.60 \pm 0.46^{6}$. The finding of the present study is also similar to the study result of Rasu and Gupta, who considered the critical level of serum magnesium below $1.8 \mathrm{mg} / \mathrm{dl}$, indicated the view of Potnis et al., who also believed that the hypomagnesaemia may play an important role in etiology of preterm labour ${ }^{16,17}$. They considered serum magnesium level to be the diagnostic and prognostic value. In a recent study by Kamal et al. also found the mean serum magnesium level in preterm labour cases was $1.4 \mathrm{mg} / \mathrm{dl} \pm$ $0.22 \mathrm{SD}$ and concluded that the estimation of serum magnesium may prove to be a valuable tool in predicting the preterm onset of labour ${ }^{17}$. Begum et al. also observed that there was significant reduction $(\mathrm{p}<0.001)$ of serum magnesium (mean $1.77 \pm 0.36$ ) in women with preterm labour ${ }^{14}$. The statistical analysis of the present study shows that the proportion of low serum magnesium level (Table III) is high (60\%) among the patients with preterm level compared to normal labour (32\%). On the contrary, the proportion of normal serum magnesium was higher (68\%) among the pregnancy with normal labour compared to the preterm labour (40\%). This was statistically significant $(\mathrm{p}<0.001)$.

Therefore analysis of the present study also revealed that the proportion of preterm labour was high among the patients with serum magnesium level less than $1.9 \mathrm{mg} / \mathrm{dl}$ compared to those who had serum magnesium level 1.9 $\mathrm{mg} / \mathrm{dl}$ or more and the difference was statistically significant $(p<0.001)$. This was also supported by the estimation of relative risk. That the patient with low serum magnesium level $(<1.9 \mathrm{mg} / \mathrm{dl})$ has 3.188 times more risk to have preterm labour than those who had the normal serum magnesium level $(>1.9 \mathrm{mg} / \mathrm{dl})$. The lower serum magnesium level therefore reflected the tendency of preterm labour or initiation of preterm labour. Therefore, they suggested that there is a strong role of magnesium in pathophysiology of preterm labour and recommended that the estimation of serum magnesium in pregnancy may be a valuable parameter of predicting preterm labour. From the above findings and analysis we can suspect that the low serum magnesium is associated with preterm onset of labour and also can suggest that the hypomagnesaemia may be used as a predictor of preterm labour. 
The history of previous preterm labour is the most important predictor for preterm labour. In this present study, the serum magnesium level are found reduced in the patient with history of previous preterm labour than that of the patient with no history of previous preterm labour. But it is not shown to be statistically significant. The present study also has shown that there is a relative risk, indicated the risk of preterm labour is 2.190 times higher among the patient with history of previous preterm labour. Similar result was found by Carr-Hill and Hall (1985), they found the risk of recurrent preterm labour for those whose first delivery was preterm increased 3 fold compared with women whose first infant reached term ${ }^{18}$.

Karzel (1991) and Cunze et al. (1995) in their study showed that there is a decrease in magnesium in myometrium and in plasma in pregnancy, which is more in preterm labour ${ }^{6,8}$. The magnesium level of plasma correlates with magnesium in the myometrium. This result indicated that hypomagnesaemia during pregnancy decrease the magnesium level in the myometrium. Similar observation is also made in the present study, but due to some limitations of the present study the magnesium level of the myometrium could not be determined. In another study conducted by Cunz et al. (1995) on magnesium and calcium concentration in the pregnancy and non pregnant myometrium and was concluded that, a low magnesium concentration in the pregnant human myometrium could be a cause of preterm labour. ${ }^{9}$ Magnesium is a required cofactor in the myometrial contractile response and low extracellular magnesium level may result in increased contractility. Sjogren and Edvinsson (1988) demonstrated that extracellular magnesium influences the release of calcium from intracellular depot, a decrease in extracellular magnesium result in an increase in the total exchangeable and intracellular calcium fraction with a resultant increase smooth muscle tension ${ }^{19}$.

Hall et al. (1959) found that labour was prolonged when magnesium sulphate was used in patient in eclampsia ${ }^{20}$. Steer and Petric (1977) reported that magnesium sulphate was superior to alcohol as a tocolytic agent ${ }^{21}$. Magnesium sulphate was found to be very effective as primary tocolytic agent with minimal side effect. Elliot (1983), Spisso et al.(1982) and WallMorse et al. (1995) found that tocolysis with magnesium sulphate to be successful, inexpensive and relatively nontoxic ${ }^{11,12,13}$. An epidemiological study conducted by Kuti (1981), a double blind clinical trial by Conradt et al (1988) and also by Spatting et al (1988) established that prophylactic oral magnesium supplementation to patient at risk for preterm labour was successful in lowering the preterm delivery rate and to avoid preterm labour intake should be sufficient to maintain serum magnesium level at the range of $2.0-3.5 \mathrm{mg} /$ d1. So prophylactic oral magnesium application is effective and safe, and it can be recommended with out reservation ${ }^{22,23,24}$.

The present study with all above studies support that there is an association between hypomagnesaemia and preterm labour and the hypomagnesaemia may be used as a marker or predictor of preterm labour.

The objective of this study was to formulate a proposition that would help in reducing perinatal mortality and morbidity by preventing preterm birth. Prophylactic oral magnesium supplementation to the patients with higher risk for development of preterm labour may be successful for prevention of preterm labour, as there may be relative deficiency due to increased demand. Further studies are required to find out the etiology of irritability of uterus due to low level of serum magnesium , to evaluate the role of magnesium in preterm labour and the probability of use of low serum magnesium as a marker or predictor of idiopathic group of preterm labour.

\section{References:}

1. Arius, F. Preterm Labour. In: Practical Guide to High Risk Pregnancy and Delivery. 2nd ed. USA: 1993. p. 71-99.

2. Leitich H. Secondary Predictors of Preterm Labour, British J Obstet Gynaecol. 1995; 112(1): 48-50.

3. Moutquin JM. Effectiveness and Safety of the Oxytocin Antagonist Atosiban vs. Beta-adrenergic Agonist in the Treatment of Preterm Labour, Br J Obstet Gynaecol. 2001; 108: 133-42. 
4. Lumley, J. Defining the Problem: the Epidemiology of Preterm Birth, Br J Obstet Gynaecol, 2003; 110: 3-7.

5. Peacock, J.L., Bland, J.M., Anderson, H.R. Preterm Delivery; Effect Socioeconomic Factors, Psychological Stress, Smoking, Alcohol, and Cffeine, BMJ, 1995; 311: 531.

6. Kurzal, R.B. 'Serum Magnesium Level in Pregnancy and Preterm Labour', Am J Perinatol, 1991; 08: 119-27.

7. Pushpo, D., Jagdish, W.M.A. A Study of Serum Mgnesium Level in Preterm Labour, The $\mathrm{J}$ of Obstet Gynaecol India, 1991; 41: 269-73.

8. Le Bouedec, G., Begon, G., Monteillard, C., Gioanni, G., Pignide, L., Bruhat, M.A. Magnesium and the Threat of Premature Labour, J Obstet Biol Reprod (Paris), 1989; 18: 53-60.

9. Cunze T, Rath W, Osmer R, Martin M, Warneke, G., Kuhn, W. Magnesium and Calcium Concentration in Pregnant and Nonpregnant Myometrium. Int J Obstet Gynaecol, 1995 ; 48: 913.

10. Elliot, J.P. Magnesium Sulphate as a Tocolytic Agent, Am J Obs Gynecol, 1983; 147: 277.

11. Watras, J. Effect of $\mathrm{Mg}+2$ on Calcium Accumulation by Two Fraction of Sarcoplasmic Reticulum from Rabit Skeletal Muscle, Biochem Biophys Acta. 1985; 812: 333-44.

12. Spisso, K.R., Harbert, G.M. Jr., Thiagarajah, S. The Use of Magnesium Sulphate as Primary Tocolytic Agent to Prevent Premature Delivery, Am J Obstet Gynecol. 1982; 142: 840.

13. Rick, W.M. Oral Magnesium and Prevention of Preterm Labour in High Risk Group of Patient, Am J Obstet Gynecol. 1992; 166: 144-7.

14. Begum H, Shamsuddin, L., Khatun, S. Relationship of Preterm Labour with Serum Magnesium Level. Bangladesh J Obstet Gynaecol. 2004; 19(1): 3-6.

15. Bohoun, C. Clin. Chim. Acta, 1962; 7: 811-17

16. Potnis, A.V, Patel, P.U., Purandare, B.N. Influence of Serum Magnesium Level In Preterm
Labour, The J of Obstet Gynaecol India, 1977; 28: 342 .

17. Kamal, S., Sharan, A., Kumar, U., Shahi, S.K. Serum Magnesium Level In Preterm Labour, Indian J Pathol Microbiol. 2003; 46: 271-273.

18. Carr-Hill, R.A., Hall, M.H. The Repetition of Spontaneous Preterm Labour. British J Obstet Gynaecol. 1985; 92: 921.

19. Sjogren, A., Edvinsson, I. The Influence of Magnesium on Release of Calcium from Intracellular Depot in Vascular Smooth Muscle Cells. Pharmacol Toxicall. 1988; 62: 17-21.

20. Hall, D.G. Serum Magnesium in Pregnancy. Obset Gynaecol. 1957; 9: 158-162.

21. Steer, C.M., Petrie, R.H. .A Comparison of Magnesium Sulphate and Alcohol for the Prevention of Premature Labour. Am J Obstet Gynecol. 1977; 129: 1

22. Kuti, V., Balaz, M., Morvay, F., Vatenka, Z., Szekely, A. Effect of Mternal Magnesium Supply on Spontaneous Abortion and Premature Birth and on Intrauterine Fetal Development- Experimental Epidemiologicl Study., Magnesium Bulletin, 1981; 3: 73-79.

23. Conradt, A., Weidinger, H. The Importance of Betamimetics and Magnesium for Pregnancy. $\mathrm{Z}$ Geburtshilfe Perinatol. 1983; 187(3): 127-137.

24. Spatling, L. Magnesium in Obstetrics and Gynaecology. Gynakol Geburtshilfliche Rundsch. 1993; 33: 85-91.

25. Smolarczyk, R., Wojcicka-Jagodzinska, J., Romejko, E., Piekaski, P., Czajkowski, K., Teliga, J. Calcium - Phosphorus - Magnesium Homeostasis in Women with Threatened Preterm Delivery. Int J Obstet Gynaecol. 1997; 57: 44-48.

26. Wojcicka, J., Romejko, E., Piekarski, P., Cjazcowski, K., Smolarczyk, R., Lipinski, T. Second Trimester Calcium - Phosphorus Magnesium Homeostasis in Women with Threatened Preterm Delivery. Int $\mathrm{J}$ Obstet Gynaecol, 1998; 61: 121-125. 